\title{
Working Around the Military Challenges of Military Spouse Employment
}

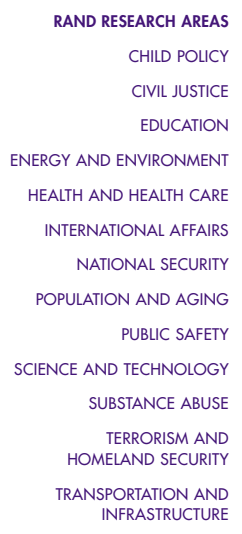

This product is part of the RAND Corporation research brief series. RAND research briefs present policy-oriented

summaries of individual published, peer-reviewed documents or of a body of published work.

Corporate Headquarters 1776 Main Street P.O. Box 2138 Santa Monica, California

90407-2138

TEL 310.393 .0411

FAX 310.393 .4818

(C) RAND 2005

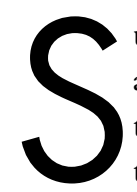

uccessful recruiting and retention of the active duty force depends in large part on the extent to which service members and their spouses are satisfied with the military lifestyle. Prior research suggests both that the most satisfied military families are those with an employed spouse and that the influence of military spouses on service member retention decisions has increased with the proportion of military spouses working outside the home.

The majority of military spouses are employed. Nonetheless, the RAND Corporation finds that they are less likely to be employed, are more likely to be seeking work, and earn less than comparable civilian spouses.

Common explanations for their different employment outcomes are that military spouses tend to be younger, which influences their earnings and employability; that they may choose not to work; or that there may be aspects of the military lifestyle that preclude their employment or affect the types of jobs they accept (and thus their earnings).

To parse these varied explanations and gain a more detailed picture of military spouse employment, RAND researchers characterized military spouse employment based on the analysis of available Census and other data, including the personal perceptions and experiences of military spouses gained from interviews with more than 1,100 military spouses. The goal was to consider the demographics of military spouses, such as age, education level, or number and age of children, as well as less observable factors, such as spouse's interest in work, employer biases against military spouses, or the impact of the military lifestyle on the service member's family.

\section{Who Are Military Spouses?}

Military spouses differ from their civilian counterparts in ways that could explain workforce participation levels. For instance, as befits popular

\section{Key findings}

- Military wives are employed at lower rates and earn less than civilian wives, on average.

- Civilian wives with the same characteristics as military wives actually have better employment outcomes than the average civilian wife.

- The majority of military spouses believe that the military lifestyle-including frequent moves, deployments and long hours that keep service members from assisting with parenting, and living in areas with poor local labor market conditions - has negatively affected their employment opportunities. Almost half believe that their educational opportunities have suffered.

- Military spouses work for different reasons, based on their own education level, their service member's pay grade, and their financial situation.

conceptions, military spouses are more likely to experience frequent long-distance relocations, and are on average younger and thus more likely to have young children at home. Conventional wisdom also tends to envision these spouses in rural locales that limit their employment options and wages. In reality, however, military wives ${ }^{1}$ are more likely than civilian wives to live in metropolitan areas. Moreover, they are more likely to have graduated from high school and to have some college education, which ostensibly would increase their employability. But to what extent, then, are their employment outcomes the result of their age, their frequent moves, or other observable attributes?

\footnotetext{
${ }^{1}$ Due to the small numbers of male spouses, the quantitative analysis of Census and other data included only female spouses of male service members.
} 
To answer that question, researchers compared military spouses with civilian "look-alikes" who share the same age, education level, ethnicity, and even frequency of moves. The comparison revealed that the look-alikes generally fared both better than the military spouses and better than the civilian average. In other words, the demographics of military spouses suggest that they should have better employment outcomes and higher wages than the average civilian spouse. Instead, however, they are employed at much lower rates and earn less than both the average civilian spouse and those who exhibit the same characteristics. Moreover, RAND compared military spouses specifically with civilian spouses residing in the same metropolitan areas and found that military spouses earn less than their civilian neighbors.

\section{A View from the Inside: What the Spouses Themselves Say}

By eliciting spouses' views about their reasons for working or staying at home, their experiences in or out of the labor market, and what they believe about the impact of military life on their employment and educational opportunities, the interviews done as part of this research paint a richer portrait of the relationship between employment status and the conditions of a military lifestyle.

\section{One size won't fit all. Reasons for working differ among groups of spouses}

To formulate policies to improve employment, it is important to understand spouse motivations for working. About three-quarters of interviewed spouses who were either employed or seeking work mentioned financial reasons for working, with working to pay bills and cover basic expenses as the most widely cited primary reason. The majority of spouses also discussed nonmonetary motives such as working to avoid boredom and keep busy, working for personal fulfillment or independence, or working to maintain skills and career status.

Spouses' motivation for working varied based on the pay grade of the service member, the family's financial situation, and the education and occupation of the military spouse. For example, personal fulfillment or independence was a nonfinancial primary reason for working that was widely cited by better-educated spouses and those married to officers. Spouses with less education, married to morejunior enlisted service members, and in more challenging financial circumstances tended to cite financial necessity as their primary reason for working.

\section{Many spouses opt out of the workforce because of conditions unique to the military lifestyle}

Just as revealing are the reasons offered by those spouses who are neither employed nor seeking employment. The vast majority (approximately three-quarters) of spouses out of the labor force mentioned full-time parenting responsibilities as their reason for not working. While some of these spouses prefer to remain out of the labor force, not all stay-at-home spouses lack a "taste" for work. A sizable number of spouses neither working nor seeking work mentioned barriers, including day care problems, local labor market conditions, or demands of the military lifestyle, that hinder their employment. Although day care and local labor market conditions are issues that large numbers of civilian spouses also face, many military spouses viewed these conditions as the result of their military lifestyle, either because they were removed from extended family that could help with the parenting responsibilities, because they would not have self-selected the location to which the military sent them, or because military demands such as deployments and long hours precluded their service member from assisting them.

\section{A majority believe that military life negatively affected their employment and education}

The clearest indicator of the challenges of military spouse employment is the fact that almost two-thirds of those interviewed felt that being a military spouse had a negative impact on their work opportunities. The most frequently cited cause was frequent and disruptive moves. Other causes cited were service member absence and the related heavy parenting responsibilities as well as child care difficulties. These spouses also referred to the inflexibility of the military workplace to accommodate the needs of military parents. Finally, some spouses cited an employer bias against or stigmatization of military spouses, often driven by the employer's concern that the spouse will be forced to leave abruptly. As with frequent moves and service member absence, this perceived cause is uniquely military.

Many spouses also reported a negative impact on their education. Almost half the spouses believed that their educational opportunities had suffered negatively, once again citing frequent moves and service member absence.

\section{Steps to Improve Employment and Educational Opportunities and Thus Enhance Quality of Life} When asked what the military might do to improve their employment and educational opportunities, the spouses' most common recommendation was that the Department of Defense (DoD) increase the affordability and accessibility of both education and military child care programs.

Given these and other spouse suggestions and this study's findings, RAND researchers generated the following recommendations for DoD to consider in addressing and improving military spouse employment:

- Design employment programs or policies that recognize that different groups of spouses work for different reasons.

- Continue to address military child care availability and affordability, including extended-hours and part-time child care.

- Pursue relationships with local employers and large, nationally prevalent employers to improve hiring conditions for military spouses.

- Consider incentives or requirements for military contractors to prioritize hiring military spouses.

- Reexamine the priority system for civil service jobs, including whether military spouses should receive higher priority than nonretiree veterans.

- Address licensing and certification hurdles to help relocating spouses continue their careers.

- Raise awareness about existing spouse employment programs. 
- Become a more family-friendly employer, including better informing families about their service member's schedule and creating more ways for service members to help their spouses with the "crises" of parenthood.

Moreover, the researchers recommended that DoD determine its official position on military spouse education and develop a policy statement to reflect this position. The policy statement should be the basis of how, and establish the extent to which, DoD should encourage, support, or even invest in military spouse education. Depending on the extent of DoD support for military spouse education, the department could address spouse education through such means as

- encouraging education providers to maximize the number of classes offered on military bases and ease the administrative difficulty of transferring courses

- pursuing in-state tuition rates for military spouses

- creating online or distance-learning opportunities.
These findings provide an expansive portrait of military spouse living and working conditions. The quantitative data available confirm the perceptions and experiences of many of the military spouses interviewed and demonstrate that many military spouses make personal employment or academic sacrifices to support their service member spouse's career demands. The strains posed by frequent moves, long spouse absences, and related child care dilemmas are products of the military life. And these strains can play a role in service members' leaving the military to pursue what they perceive to be more family-friendly professions. But by taking some or all of these steps, DoD could reap rewards both in terms of concrete quality-of-life improvements and in general perceptions among service members and spouses that the military is listening to, and acting on, their concerns. 
This research brief describes work done for the National Defense Research Institute and documented in Working Around the Military: Challenges to Military Spouse Employment and Education, by Margaret C. Harrell, Nelson Lim, Laura Werber Castaneda, and Daniela Golinelli, MG-196-OSD, 2004, 232 pages, \$24, ISBN: 0-8330-3656-4. Copies of this research brief and the complete report on which it is based are available from RAND Distribution Services (phone: 310-451-7002; toll free: 877-584-8642; or email: order@rand.org) or online at www.rand.org/publications/MG/MG196/. The RAND Corporation is a nonprofit research organization providing objective analysis and effective solutions that address the challenges facing the public and private sectors around the world. RAND's publications do not necessarily reflect the opinions of its research clients and sponsors. RAND ${ }^{\circledR}$ is a registered trademark.

RAND Offices Santa Monica - Washington - Pittsburgh • New York - Doha • Berlin - Cambridge • Leiden

RB-9056-OSD (2005) 


\section{RAND}

NATIONAL DEFENSE

RESEARCH INSTITUTE

CHILD POLICY

CIVIL JUSTICE

EDUCATION

ENERGY AND ENVIRONMENT

HEALTH AND HEALTH CARE

INTERNATIONAL AFFAIRS

NATIONAL SECURITY

POPULATION AND AGING

PUBLIC SAFETY

SCIENCE AND TECHNOLOGY

SUBSTANCE ABUSE

TERRORISM AND HOMELAND SECURITY

TRANSPORTATION AND INFRASTRUCTURE
This PDF document was made available from www.rand.org as a public service of the RAND Corporation.

This product is part of the RAND Corporation research brief series. RAND research briefs present policy-oriented summaries of individual published, peerreviewed documents or of a body of published work.

The RAND Corporation is a nonprofit research organization providing objective analysis and effective solutions that address the challenges facing the public and private sectors around the world.

\section{Support RAND}

Browse Books \& Publications

Make a charitable contribution

For More Information

\author{
Visit RAND at www.rand.org \\ Explore RAND National Defense Research Institute \\ View document details
}

Limited Electronic Distribution Rights

This document and trademark(s) contained herein are protected by law as indicated in a notice appearing later in this work. This electronic representation of RAND intellectual property is provided for non-commercial use only. Permission is required from RAND to reproduce, or reuse in another form, any of our research documents for commercial use. 